\title{
Designing ESP Textbook for Pharmacy Students Based on Needs Analysis and CIPP (Context, Input, Process, Product) Evaluation Model
}

\author{
Sukisno* Ahmad Wildhan W. Wardaya \\ School of Pharmacy, STIKes Muhammadiyah Kuningan, PO box 45552, Cigugur-Kuningan, Indonesia
}

\begin{abstract}
This research aimed to explore pharmacy students' needs on ESP materials and to design ESP textbooks for pharmacy students based on the needs analysis. This research used descriptive qualitative design. The data were collected from needs analysis questionnaire, evaluation questionnaire by using CIPP model and interviews, then they were described in narrative form. Based on the data obtained from CIPP evaluation, the average of students on context evaluation expected that teaching materials should be designed according to the needs, opportunities and benefits to support their academic and career after graduation. Through input evaluation, students want the materials to be in line with the needs of students and syllabus. Meanwhile, physically, students want the textbook has an attractive appearance, both from cover and from pictures. In addition, they also want the textbook has lesson objectives for each unit, has clear instructions and systematic for each activity and covers all language skills. Process Evaluation consisted of five aspects of assessment; aspect of feedback to the topics discussed in textbook, aspect of reading, speaking, writing and listening skills. The result of this evaluation, the average of students stated that not all materials are useful for students, and the important materials that can improve their reading, speaking, writing and listening skills must be included in the textbook. The result of product evaluation, most of students stated that the present ESP textbook was not relevant or not in line with the curriculum and their needs. Based on the analyzing and interpreting data obtained from needs analysis, it can be concluded that the English syllabus and materials developed should be based on students' needs. English topics for pharmacy based on data obtained, namely: Greeting and Introducing Oneself and Others, Definition and Scope of Pharmacy, Pharmacist Duties and Responsibilities, Pharmacy Services, Medical Prescription, Dispensing Medication, Hospital Pharmacy, Herbal Medicine, Drug Classifications, Drug Information Services, Pharmaceutical Industry, Diseases and Illness, Virus, Epidemic \& Pandemic, and Corona Virus (Covid-19).
\end{abstract}

Keywords: Designing ESP material, Needs analysis, CIPP evaluation model, Pharmacy student

DOI: $10.7176 / \mathrm{JEP} / 12-29-06$

Publication date:October $31^{\text {st }} 2021$

\section{Introduction}

Textbook designing and development is part of ESP courses because of the attempt to offer teaching materials which in line with specific field area and students' needs of a certain group of students. The textbooks fit to the needs of a specific group of students are not likely to be available since publishers are understandably reluctant to produce it for limited markets. When the suitable textbooks are available in the market but they are not easy to get and many of them lack of the content and imagination required to be considered appealing and relevant. Therefore, ESP textbook needs to be designed and developed by the lecturer for enhancing the reputation of an educational institution as a visible and tangible product of activity.

The development of English for Specific Purposes (ESP) which is part of the English Language Training (ELT) continues to develop from time to time along with the rapid development of science and technology as well as the industrial era 4.0 which requires English to give information related to a particular field of study including in pharmacy field.

An ESP course for pharmacy student is intended to help them study their subject matter and in their career in the future. It seems that English plays a very vital role in pharmaceutical studies because the students have to read medical textbooks and professional journals which are mostly written in English (Hutchinson and Waters, 1987). Therefore, needs to be an effort from the institution or from the lecturers themselves to provide teaching materials that are relevant and in line with the students' field of study.

In relation to Curriculum, designing materials should be adapted with learners' need of studying English for pharmacy. As stated by Yalden that setting up a new course implies a skillful blending of what is already known about language teaching and learning with the new elements that a group of learners bring to the classroom; their own needs, wants, attitudes, knowledge of the world (Harimansyah W et al., 2008). It contains similar elements to those contained in a common curriculum that adapted to the Indonesian National Qualifications Framework (INQF/KKNI) and National Standard of Indonesian Higher Education (SN-Dikti) 2015 and the development of science and technology.

In addition, to the approaches above, planning of ESP textbook will be designed for an ESP program that 
focusing mostly on task-based instruction (TBI), and will be designed especially for pharmacy students. According to Hutchinson and Waters suggest that the best work in the ESP area usually focuses on a process rather than a product (Stufflebeam and Millman, 1995). So, to begin design process the researcher conducted evaluation by using CIPP evaluation model to the present English textbook and a need analysis to pharmacy students. To overcome this, the researcher decided to design ESP Textbook based on Needs Analysis and CIPP evaluation model.

\section{Literature review}

\subsection{English for Specific Purposes}

According to Richard and Schmidt, English for Specific Purposes (ESP) is a language course or teaching program in which the content and objectives of the course are determined by the special needs of a particular group of learners (Richards, 2001). ESP organizes learners from various fields to use English for academics, and used for professional purposes such as used by doctors, engineers, pharmacists, nurses and other health care professionals.

While Hutchinson and Waters, ESP is defined as "an approach to language teaching in which all decisions about content and methods are based on the learner's reasons for learning" (Hutchinson and Waters, 1987). The development of ESP can be traced since the 1960s, but ESP is still a relatively new area in the long history of language instruction (Albakrawi and Almutairi, 2013). Dudley-Evans and St. John, mentioned that ESP has become a vital and innovative activity in the movement of Teaching English as a Foreign and Second Language (Dudley-Evans, St John and Saint John, 1998).

\subsection{Needs Analysis}

According to McKillip Needs are value judgments: that a target group has problems that can be solved (McKillip, 1987). Needs analysis involves the identification and evaluation of needs and as a tool for decision making in education and human service. In other words, needs analysis is the process of evaluating identified problems and solutions for the target population emphasizing the importance and relevance of problems and solutions.

Needs analysis is also as a method that cannot be separated from the development of learning materials and curriculums, especially ESP. As stated by Basturkmen that needs analysis is the identification of a language and skills used in determining and selecting ESP-based learning materials (Basturkmen, 2010). It can also be assessment to the learners and learning process at the end of learning period.

Procedure of gathering information on the needs of learners is known as needs analysis. As mentioned by Nunan that needs analysis is the process of gathering information concerning needs of learners (Nunan, 1992). Therefore, before taking out the analysis, the difference between learning needs and target needs should be first identified. In addition, Hutchinson and Waters classify the needs into target needs and learning needs (Hutchinson and Waters, 1987). It's mean that what learners need to be able to communicate in the target situation and what learners need to learn. Then according to Hutchinson and Waters state that analysis related to target situation that include what language aspects are needed by the learners to reach the target effectively (necessities), what learners have not mastered (lacks), and what learners want to learn (wants).(Hutchinson and Waters, 1987).

\subsection{CIPP Evaluation Model}

The CIPP evaluation model is an evaluation model consisting of four evaluation components: Context, Input, Process, and Product. CIPP is an of Context Evaluation means evaluation of Context, Input Evaluation means evaluation of input, Process Evaluation means evaluation of Process, and Product Evaluation means evaluation of results. By looking at the explanation, then the evaluation step is to analyze the program based on its components. Arikunto states that the CIPP Evaluation Model is a comprehensive framework for guiding evaluations of programs, projects, personnel, products, institutions, and systems (Arikunto, 2008).

Context Evaluation: describes the relevant environment, identify needs and opportunities and diagnose certain problems. Arikunto, describes in detail the evaluation of the CIPP model (Arikunto, 2008). Context evaluation is an attempt to describe and detail the environment, unmet needs, populations and samples served, and objectives. Input Evaluation: is designed to provide information and determine how to utilize resources to meet program goals. According to Arikunto Input evaluation is an evaluation that aims to provide information to determine how to use available resources in achieving program objectives (Arikunto, 2008). Process Evaluation: provides feedback on individual responsibilities in terms of implementation. This can be met by monitoring the source of the failure, providing information in deciding the initial plan during the implementation and explaining what really happened. Arikunto also said that process evaluations assess the implementation of plans to help staff carry out activities and later help the board group of users' judge program performance and interpret outcomes (Arikunto, 2008). Product Evaluation: measure and interpret the achievement of program objectives. As Arikunto stated that Product evaluations identify and assess outcomes-intended and unintended, short term and 
long term-both to help a staff keep an enterprise focused on achieving important outcomes and ultimately to help the broader group of user gauge the effort's success in meeting targeted needs (Arikunto, 2008).

\subsection{Designing ESP Materials}

In language teaching, materials are defined as anything which is used to help to teach language learners. As stated by Tomlinson that materials can be found in the form of a textbook, a workbook, a cassette, a CD-ROM, a video, a photo-copied handout, a newspaper, a paragraph written on a white-board: anything which presents or informs about the language being learned (B. Tomlinson, 1998).

According to Valle developing materials for the ESP classroom is a trade-off between learning needs, language content and subject-matter content which implies the review of a number of issues (Bocanegra-Valle, $2010)$; 1) What is the target topic/what will be the carrier content? 2) Is this topic relevant for my students/the discipline? 3) What do I, as an ESP practitioner, know about the carrier content? 4) What are my students supposed to know about the carrier content? 5) To what extent do materials reflect the language/conventions of the discipline? 6) What are the learning goals? 7) What is the target language form/function/skill? 8) What materials are available, suitable and accessible? 9) What teaching equipment is required and available? 10) How much time should be spent on the design, development and implementation of activities? 11) Will materials be classroom-oriented or provide additional work?

The process of ESP materials development can be seen in Figure below:

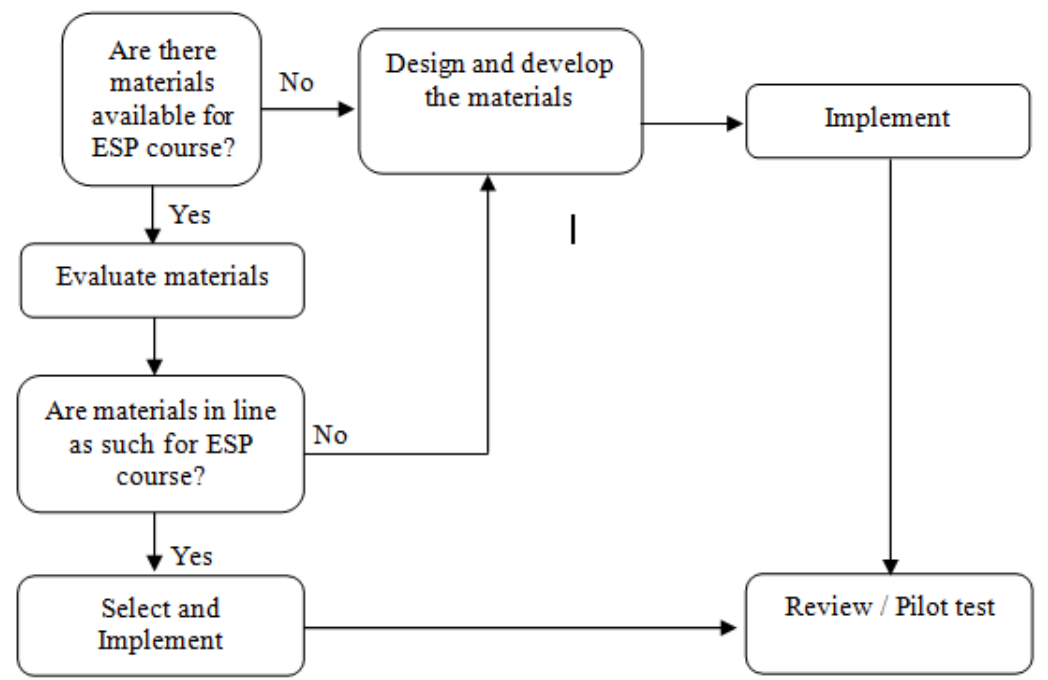

Figure 1. ESP Materials Development

\section{Methodology}

\subsection{Required Data Input}

Need Analysis and CIPP evaluation model are used to design ESP Textbook for Pharmacy Students with descriptive qualitative design. The data were collected both from questionnaires and interviews, and then they were described in the form of narrative. The data gathering instruments are used to produce a more accurate interpretation of data. To see the present ESP textbook is in line with the students' needs, questionnaires were designed based on the Richards(Ornstein and Hunkins, 1988). The questionnaire will be translated into Indonesian for better comprehension.

\subsection{Technique of Data Collection}

Before the researcher conducted needs analysis, the researcher evaluated the existing English Textbook which used by pharmacy students using CIPP evaluation model. Questionnaire and interview instruments used to collect the data. The form of questionnaire divided into several categories based on CIPP model for evaluating existing English Textbook. The reliability and validity test of the questionnaire measured before given to 30 pharmacy students. Then, the researcher conducted needs analysis to know student's needs to the materials.

\subsection{Validity and Reliability}

To test the validity of the questionnaire, the researcher used construct validity, namely the preparation of questionnaire concepts based on theories related to research variables, and pay attention to the opinions of experts. In addition, to test the validity of the instrument, the researcher conducted trials to another 30 pharmacy students. The results obtained are consulted with the table, if the count value (rxy) $>r$ table $(0,361)$, then the 
question is declared valid.

To test the reliability of the instrument, the researcher used internal consistency with the instrument tested once, and then the result analyzed by using SPSS program version 22. In theory, the reliability coefficient ranges from 0 to 1 . An instrument is declared to have lower reliability if the further down value 1 , and the higher the reliability if closer to the value 1 . Reliability is a measure to indicate that a reliable instrument to be used as a means of collecting data for the instrument is considered good. Reliability test instrument can be done by using Cronbach's Alpha through SPSS, by comparing $\alpha$ value with $r$ table from product moment correlation.

\subsection{Method of Data Analysis}

The data collected through questionnaires that compiled, and then the SPSS program employed to analyze the data. The students' answers in the questionnaire was examined for abnormalities and missing data. Subsequently, the data analyzed through both descriptive and inferential statistics.

The interview sessions was recorded, replayed, and transcribed. After transcribing the result of the interview, then it was analyzed and classified into some categories based on the questions arisen. The researcher appraised all of the data including from document and interview as the supporting data. The last, the data of interview was analyzed by using display technique.

\section{Finding and Discussion}

This research aimed to answer two main objectives: 1) to explore the needs of pharmacy students for ESP material and 2) to design an ESP textbook for pharmacy students based on needs analysis with questionnaire of needs analysis, questionnaire of evaluation by using CIPP model and interviews.

\subsection{CIPP Evaluation}

Context Evaluation: The purpose of collecting data in this context evaluation was to provide answers to the research objectives. According to Ornstein \& Hunkins, its purpose is to define the relevant environment, describe the desired and actual conditions related to that environment, focus on unmet needs and missed opportunities and diagnose the reasons for unmet needs (Ornstein and Hunkins, 1988). This is in line with the opinion of Hutchinson and Waters, ESP is defined as an approach to language teaching in which all decisions regarding content and methods are based on the learner's reasons for learning (Hutchinson and Waters, 1987). So, in this evaluation of context the researcher portrayed a relevant learning environment and identified pharmacy students' needs for English and opportunities and diagnosed certain problems. The data were collected from 30 pharmacy students through 15 questions. From the analysis of the evaluation context can be concluded that the average $77.6 \%$ of students wanted or expected to learn English language can support their work after graduation, to support academic, provide benefits that students are able to read and understand the text books, magazines and articles in English, becoming speakers who are more fluent, more accurate, expand general and specific vocabulary, expand specialization, improve their listening skills, pronunciation, reading and writing skills and also they agree that the difficulty of learning English is in speaking, writing and listening skills. From the results of interviews with alumni of pharmacy program (code: 1.RI-2345 on the English Mastery aspect) that English mastery is very important to support their careers, with English skills the opportunity to get a job is very wide. Not only that, with English skills that are in accordance with their fields, students and graduates of pharmacy can take part in international seminars on pharmacy, understand journals or pharmaceutical materials in English and we can easily master and follow technological developments in the industrial era. 4.0. According to W. Harimasyah, et al, a textbook can be said both in terms of material when considering the complete reference, which is in accordance with the curriculum or syllabus compiled, relevant science, the ability of the language needs of learners (Harimansyah W et al., 2008). So, it is clear that the media, in this case the ESP textbooks used, were not in line with the wishes and goals of the students themselves.

Input Evaluation: Input evaluation was designed to provide information and determine how to utilize resources to achieve program objectives. Stufflebeam \& Shinkfeld stated that the purpose of input evaluation is to help clients consider alternatives in relation to their particular needs and circumstances and to help develop a plan that can be implemented for them (Stufflebeam and Millman, 1995). Based on the results of data collection through 30 students with 10 questions, the average $77.3 \%$ of students stated strongly agree and agree to give input on learning English using textbooks that English syllabus must be in line with the needs of pharmacy students, textbooks for pharmacy students must be appropriate with the syllabus, the textbook must have an attractive cover design, the topic of the textbook must be equipped with audio and video media, the text book must be equipped with attractive and colorful pictures, the textbook must have systematic clarity, the textbook must have a clear learning objective in each chapters/units of material, textbooks must cover all language skills ( Reading, Speaking, Writing and Listening ), and all activities in textbooks must be in line with the daily activities of pharmacy students, textbooks must have clear instructions for each activity. Tarigan \& Tarigan defines that a good textbook is a text book that can make students want, happy to do anything that is included in textbooks, and 
increase student interest (Tarigan and Tarigan, 1986). So, it is clear that a good textbook can not only be seen from the content aspect, physically, it must also have a good appearance. Appearance will support the content, without the good appearance most of students will not be interested to read it, and without good content, most of students will not understand what is contained in the textbook. From the results of the input evaluation research, it can be concluded that the textbook used was less attractive to students from a physical point of view, starting from the cover, illustrations, and the appearance of each unit/chapter, as well as color.

Process Evaluation: evaluation process was designed to provide information about the feedback of the English textbook implementation used by students. The data obtained from 30 students consisted of five aspects for assessment, each aspect of the assessment consisted of several questions: 1) Feedback on topics discussed in textbooks: The results of data analysis on feedback on topics discussed in textbooks showed that the average $(52.0 \%)$ of students considered not very useful, not useful and somewhat useful and $48.0 \%$ considered strongly useful and useful to the topic/material: (1) The Pharmacist, (2) Allergy, (4)The Function of Nutrition, (5) Sugar Contain, (6) The Development of Pharmaceutical Industry, and (7) Psychiatric Drugs In Medical Practice. From these results it can be said that not all subject matter in the textbook were useful for pharmacy students. 2) Reading Skills Variable: The results of data analysis for reading skills aspects that $78.3 \%$ students stated reading the manual book, instruction, products specification, price lists, prescription, and legal documents are important and strongly important. It can be concluded that important material that can practice their reading skills should be included in the textbook. It means that reading materials of the textbooks did not significantly improve students' reading skills. 3) Speaking Skills Variable: The results of data analysis in speaking skills aspects that $69.0 \%$ students stated talking with customer / foreign patients, being an accurate speaker, speaking to foreign colleagues, speaking on the phone, get involved in a meeting, attending conferences, giving presentations, giving instructions, small talk, and discussions are important and strongly important. From the statement of pharmacy students, it can be concluded that important material that can practice their speaking skills should be included in the textbook. 4) Writing Skills Variable: The results of the data analysis in writing skills $78.3 \%$ students expressed that write application form, write prescriptions, write reports, write articles, write a summary of the articles, write a notes, make a brochures and write glossary / list of words is important and strongly important. From the statement of the pharmacy students, it can be concluded that important material that can practice their writing skills should be included in the textbook. This means that the writing material in the textbook used did not significantly improve writing skills. 5) Listening Skills Variable: The results of data analysis on listening skills aspect showed that $73.3 \%$ of students stated that listening directly from the lecturer, listening to instructions, listening to presentations, listening to explanations given by lecturer, listening to the speech, and listening to online/offline audio is strongly important and important. It can be concluded that important material that can practice their listening skills should be included in the textbook. This means that listening material from textbooks used did not significantly improve students' listening skills.

Product Evaluation: The purpose of collecting data at this evaluation stage was to measure and interpret the achievement of program objectives in this case the product or content of the textbook used as a medium for learning English by pharmacy students. Stufflebeam \& Shinkfeld (1985: 176) stated that the main function of product evaluation is to measure, interpret, and assess the achievement of a program, ensuring how much the program has met the needs of a group being served (Stufflebeam and Millman, 1995). The results showed that of the 30 students who filled out questionnaires of product evaluation, $70.4 \%$ students stated somewhat agree , disagree and strongly disagree that the materials and the contents of the English textbook are relevant to the needs of pharmacy students, subject and content of the textbooks in generally realistic, subject and content of textbooks is interesting, the subject and content of textbooks motivate, textbook in accordance with the syllabus, the textbook in accordance with the curriculum, Grammar points are presented with clear explanations, Grammar points are presented with exercise and easy task, Grammar point and vocabularies are introduced in a motivating and realistic context, topics of the textbook is sufficient to enable students to use it in their studies, the topic in this textbook is relevant to the student study program, the textbook covers all four skills (Reading, Listening, Writing and Speaking), and pictures in textbooks relevant to the topic of the text. Thus, from the analysis of product evaluation can be concluded that most of students stated somewhat agree, disagree even some states strongly disagree. According to the results of the interview with head of pharmacy that specific English for pharmacy students was very much needed, because learning General English (GE) is not too deep to discuss their studies, namely pharmacy, for example material on herbal medicine and pharmacology. Besides, the development of English syllabus also needs to be done, because the syllabus used must be adjusted to the students' needs according to their field of study.

So English textbooks for pharmacy students must have material feasibility, cover all language skills, clear presentation, and attractive graphics or design and systematized, skills and strategies, practical considerations and illustrations, content and language exercises and most importantly, textbooks must be in line with the field of study, so that it can be used as a learning resource that can support their activities, creativity, and meet the needs of pharmacy students both for academics and for career purposes. 


\subsection{Needs Analysis}

English syllabus and materials developed must be based on needs analysis; hence this research used English for Specific Purposes (ESP) approach. According to Richards and Schmidt the role of English in a language course or program of instruction in which the content and objectives of the course are fixed by the specific needs of a particular group of learners (Richards, 2001). This is in line with stated by B. Tomlinson that the English syllabus and materials are designed to meet the specific needs of learners (B. Tomlinson, 1998). The needs analysis aims to meet the demand by many learners who need to learn English. The first step taken by researchers to develop a syllabus and design teaching materials in the form of textbooks was to evaluate the teaching materials used and conduct needs analysis. From the findings of the data analysis above, it can be concluded that pharmacy students at STIKes Muhammadiyah Kuningan need:

1) Facilities and infrastructure to support the English learning process, such as a language laboratory available to improve their English skills and avoid boredom when studying in the classroom.

2) English skills (Speaking, Listening, Reading, Writing) especially reading and speaking skills according to the results of interviews with the head of pharmacy program and alumni. As stated by Derradji, S. A, the four language skills (Speaking, Listening, Reading and Writing) are required in the context of ESP according to the needs of certain groups of learners in specific areas (Derradji, 1995).

3) English vocabularies mastery for the health area, especially in the pharmaceutical field.

4) Various English learning activities for pharmacy students are not only carried out in the classroom but can be done outside the classroom. Activities undertaken in the classroom can be done in groups or pairs or individually then conducted outside the classroom through English games or goes to some places where many native speakers of English. This is in line with what was expressed by Harmer that there are six speaking activities in class, namely: acting according to scripts, communication games, discussions, speech preparation, questionnaires, simulations and role playing (Harmer, 2004).

5) There are 14 topics of English for pharmacy needed by students based on data obtained through a needs analysis, namely: (1) Greeting and Introducing Oneself and Others. (2) Definition and Scope of Pharmacy. (3) Pharmacist Duties and Responsibilities. (4) Pharmacy Services. (5) Medical Prescription. (6) Dispensing Medication. (7) Hospital Pharmacy. (8) Herbal Medicine. (9) Drug classifications. (10) Drug Information Services. (11) Pharmaceutical Industry. (12) Diseases and Illness. (13) Virus, Epidemic and Pandemic. (14) Corona Virus (Covid-19)

In addition to designing the textbook that fit the needs of pharmacy students, the process of delivering these materials should also be choosing teaching methods are appropriate and effective so that the material can be mastered by the student well. A good method helps students understand and master the material. One of the failures to teach is not only caused by the incompatibility of teaching materials but can also be caused by inappropriate methods. The method used is often said to be the cause of success or failure in language teaching, because at the end the method determines what and how the language interaction (Mackey, 1996). Besides that, according to Viktorija Petkovska teaching English also requires good organizational and management skills and creative and innovative approach during all lesson stages, but especially so during the initial presentation stage, in order to boost students' interest and motivation. He also states that sound interactive atmosphere is also crucial for the successful realization of creative ESP teaching (Petkovska, 2015).

\section{Conclusion}

By knowing the context, input, process and product of ESP Textbook, the lecturer as a designer of the syllabus and the textbook must have a better understanding of what must and must not be included in the textbook and the next edition of the textbook should largely be based on the students' needs and goals. Similarly, performing needs analysis will help the book authors (teacher/lecturers) to strengthen their tech skills and also develop and write materials that suit with the needs of students, the objectives and content dimensions of ESP Textbook. The four macro skills (reading, writing, speaking and listening) and especially communication skills must be included in ESP course. In teaching-learning process (TLP) by using the textbook, lecturer should also be aware of the needs of the students, focus on their requirements and the most crucial, lecturer must have interesting and appropriate teaching methods. The lecturer also should evaluate and develop the textbook include more exercises about other English skills must be inserted and lesson objectives so as pharmacy students' needs get familiar with the requirements of their future job in real life situations to have professional progress. This research also suggested evaluating continuously so the textbook is always in line with development era.

\section{References}

Albakrawi, H. D. M. and Almutairi, F. M. (2013) 'The effect of ESP program on the engineering student's proficiency at the University of Tabuk', Journal of Education and Practice, 4(3), pp. 117-124.

Arikunto, S. (2008) 'Dasar-dasar evaluasi pendidikan', Jakarta: Bumi Aksara.

B. Tomlinson (1998) Materials Development in Lan- guage Teaching. Cambridge: Cambridge university press. 
Basturkmen, H. (2010) Developing courses in English for specific purposes. Springer.

Bocanegra-Valle, A. (2010) Evaluating and designing materials for the ESP classroom, English for professional and academic purposes. New York: Universidad de Cádiz.

Derradji, S. (1995) 'A Syllabus for Developing Oral Proficiency: Institute of Com-merce (Algies)', University of Constantine.

Dudley-Evans, T., St John, M. J. and Saint John, M. J. (1998) Developments in English for specific purposes: A multi-disciplinary approach. Cambridge university press.

Harimansyah W et al. (2008) Pengembangan Model Pembelajaran: Uji Efektivitas Bahan Ajar BIPA. Jakarta: Pusat Bahasa.

Harmer, J. (2004) How to Teach English: An Introduction to the Practice of English language Teaching. Malaysia: Longman.

Hutchinson, T. and Waters, A. (1987) English for specific purposes. Cambridge university press.

Mackey, W. F. (1996) Language and languages - Study and teaching. London: Longman.

McKillip, J. (1987) 'Need analysis: Tools for the human service and education', Applied Social Research Methods Series.

Nunan, D. (1992) 'Research Methods in Language teaching. Cambridge: C'. University Press.

Ornstein, A. C. and Hunkins, F. P. (1988) 'Curiculum: Principles, Foundations and Issues'. Englewood Cliffs, NJ: Prentice Hall.

Petkovska, V. (2015) 'Teaching Creatively in ESP.', Journal of Education and Practice. ERIC, 6(17), pp. 172175.

Richards, J. C. (2001) Curriculum development in language teaching. Ernst Klett Sprachen.

Stufflebeam, D. L. and Millman, J. (1995) 'A proposed model for superintendent Evaluation', Journal of Personnel Evaluation in Education. Springer, 9(4), pp. 383-410.

Tarigan, H. G. and Tarigan, D. (1986) Telaah buku tekst bahasa Indonesia. Angkasa. 